\title{
Article
}

Subscriber access provided by UCL Library Services

\section{Superhydrophobic and White Light-Activated \\ Bactericidal Surface through a Simple Coating}

Gi Byoung Hwang, adnan Patir, Elaine Allan, Sean P. Nair, and Ivan P. Parkin

ACS Appl. Mater. Interfaces, Just Accepted Manuscript • DOI: 10.1021/acsami.7b05977 • Publication Date (Web): 31 Jul 2017

Downloaded from http://pubs.acs.org on August 7, 2017

\section{Just Accepted}

"Just Accepted" manuscripts have been peer-reviewed and accepted for publication. They are posted online prior to technical editing, formatting for publication and author proofing. The American Chemical Society provides "Just Accepted" as a free service to the research community to expedite the dissemination of scientific material as soon as possible after acceptance. "Just Accepted" manuscripts appear in full in PDF format accompanied by an HTML abstract. "Just Accepted" manuscripts have been fully peer reviewed, but should not be considered the official version of record. They are accessible to all readers and citable by the Digital Object Identifier (DOI $\left.{ }^{\circ}\right)$. "Just Accepted" is an optional service offered to authors. Therefore, the "Just Accepted" Web site may not include all articles that will be published in the journal. After a manuscript is technically edited and formatted, it will be removed from the "Just Accepted" Web site and published as an ASAP article. Note that technical editing may introduce minor changes to the manuscript text and/or graphics which could affect content, and all legal disclaimers and ethical guidelines that apply to the journal pertain. ACS cannot be held responsible for errors or consequences arising from the use of information contained in these "Just Accepted" manuscripts. 


\title{
Superhydrophobic and White Light-Activated Bactericidal Surface through a Simple Coating
}

\author{
Gi Byoung Hwang a , Adnan Patir ${ }^{\mathrm{a}}$, Elaine Allan ${ }^{\mathrm{b}}$, Sean Nair ${ }^{\mathrm{b}}$, and Ivan P. Parkin ${ }^{\mathrm{a} *}$ \\ ${ }^{a}$ Materials Chemistry Research Centre, Department of Chemistry, University College \\ London, 20 Gordon Street, London, WC1H OAJ, United Kingdom \\ ${ }^{b}$ Division of Microbial Diseases, UCL Eastman Dental Institute, University College London, \\ 256 Gray's Inn Road, London WC1X 8LD, United Kingdom
}

\footnotetext{
* To whom correspondence should be addressed.

E-mail: i.p.parkin@ucl.ac.uk Tel: 44(0)207 6794669
} 


\begin{abstract}
Bacterial adhesion and proliferation on surface give a challenge in medical and industrial fields. Here, a simple one-step technique is reported to fabricate self-cleaning and antibactericidal surfaces. White, blue, and violet paints were produced using titanium dioxide nanoparticles, 1H, 1H, 2H, 2H-perfluorooctyltriethoxysilane (PFOTES), crystal violet, toluidine Blue $\mathrm{O}$, and ethanol solution. All of the painted surfaces showed superhydrophobicity in air, and even after hexadecane oil contamination, they retained water repellency and self-cleaning properties. In an assay of bacterial adhesion, significant reductions $(>99.8 \%)$ in the number of adherent bacteria were observed for all the painted surfaces. In bactericidal tests, the painted surfaces demonstrated not only bactericidal activity against $S$. aureus and $E$. coli in the dark but also induced very potent photosensitisation $(>4.4$ $\log$ reduction in the number of viable bacteria on violet painted surface) under white light illumination. The technique that we developed here is general, and can be used on a wide range of substrates such as paper, glass, polymers, and others.
\end{abstract}

Keyword: self-cleaning surface, bactericidal activity, superhydrophobic surface, E. coil, and S. aureus 


\section{Introduction}

Bacteria are one of the oldest life forms on our planet and they have developed a variety of adaptive mechanisms for the colonization of surfaces over millions of years ${ }^{1}$. Bacterial biofilms on surfaces are known to produce adverse effects in a variety of situations. In waterbased industries, including water treatment and distribution, paper manufacturing, and the operation of cooling towers, biofilms reduce water quality by influencing taste and odour and they cause corrosion of the pipe-line resulting in equipment damage ${ }^{2-3}$. In the medical field, biofilms are important contributors to hospital acquired infections (HAIs) which are the fourth leading causes of death in the U. $S^{4-5}$. Pathogenic bacteria are able to survive on surfaces within healthcare facilities for several weeks and they can be transmitted through touch by hospital workers and patients ${ }^{6-7}$. According to a report by the U.S. Center for Disease Control and Prevention (CDC) in 2007, approximately 1.7 million patients in hospitals acquired HAIs and 99,000 of these patients died during hospitalization. Further, 60$70 \%$ of HAIs were related to bacterial contamination of hospital surfaces or medical devices $8-10$.

Superhydrophobic surfaces are able to reduce bacterial adhesion, and biofilm formation and provide easy removal of bacterial cells ${ }^{11}$. Many techniques to produce superhydrophobic surfaces have been suggested including surface modification using nanoparticles, photolithography, mesoporous polymer, surface etching resulting in nanoscale surface roughness, and chemical modification ${ }^{12-16}$. However, some of these techniques require harsh conditions or complex fabrication processes, thus limiting the substrate type and geometry. Moreover, superhydrophobic surfaces are easily destroyed by mild abrasive force and readily contaminated by oil resulting in loss of water repellency ${ }^{17-18}$. 
Bactericidal surfaces kill bacteria on contact ${ }^{19}$. Such surfaces have been widely investigated for potential use in healthcare facilities, in industry, and even the home. The most common and arguably, the most important use of bactericidal surfaces is for hospital surfaces or medical devices to prevent HAIs ${ }^{20-22}$. Many techniques have been suggested for application to surfaces including silver- or copper-coated surfaces ${ }^{19,23-25}$, and photosensitive surfaces using light activated antimicrobial agents (LAAAs) ${ }^{6,26}$. Recently surface treatments using light-activated antimicrobial agents, crystal violet $(\mathrm{CV})$, methylene blue (MB) and toluidine blue $\mathrm{O}(\mathrm{TBO})$ have been investigated ${ }^{27-29}$. The dyes generate reactive singlet oxygen $\left({ }^{1} \mathrm{O}_{2}\right)$ and free radicals when they are exposed to a visual light, and the ${ }^{1} \mathrm{O}_{2}$ and free radicals produce adverse effects on bacteria resulting in cell death ${ }^{28}$. Previous studies showed that CV, $\mathrm{MB}$, and TBO can be impregnated into soft polymers thorough a swell-encapsulation-shrink process, and the dyed polymers possess potent photobactericidal activity under white light ${ }^{30-}$ 32

New attempts at developing hybrid materials have been conducted in order to improve bactericidal performance whilst maintaining prevention of bacteria attachment. Previous studies showed that the combination of superhydrophobic materials with either photocatalysts or antibacterial nanoparticles such as silver, copper, and silica retained superhydrophobicity or at least hydrophobicity. However, they typically show no photocatalytic reaction and only relatively weak bactericidal activity, indicating those materials were not effectively combined 11,33-39. We have developed hybrid materials with increased bactericidal performance and with the ability to prevent bacterial attachment. In this study, a new paint formulation with dual functional properties of self-cleaning and white light-activated bactericidal activity is described. The paints that we developed here are quite general, and can be easily applied to 
various surfaces such as glass, paper, plastic and others. Furthermore, they function even after contaminated by hexadecane oil.

\section{Experimental section}

\section{Preparation of white, blue, and violet paints}

Solution A: $1.0 \mathrm{~g}$ of $1 \mathrm{H}, 1 \mathrm{H}, 2 \mathrm{H}, 2 \mathrm{H}$-perfluorooctyltriethoxysilane (PFOTES, $\mathrm{C}_{8} \mathrm{~F}_{13} \mathrm{H}_{4} \mathrm{Si}\left(\mathrm{OCH}_{2} \mathrm{CH}_{3}\right)_{3}$, Sigma-Aldrich, St. Louis, MO, USA) was dispersed in $99.0 \mathrm{~g}$ of pure ethanol (EDM Millipore Co., Billerica, MA, USA), and for $10 \mathrm{~min}$, the mixture was agitated.

White paint: $4.0 \mathrm{~g}$ of $\mathrm{TiO}_{2}$ nanoparticles (Degussa P 25) were mixed with $40 \mathrm{~mL}$ of solution A with constant agitation, and then, for $5 \mathrm{~min}$ the mixture was sonicated and vortexed for $5 \mathrm{~min}$

Blue paint: $4.0 \mathrm{~g}$ of $\mathrm{TiO}_{2}$ nanoparticles (Degussa $\mathrm{P} 25$ ), and $40 \mathrm{mg}$ of toluidine blue $\mathrm{O}$ (TBO, Sigma-Aldrich, St. Louis, MO, USA) were dispersed in $40 \mathrm{~mL}$ of solution A with constant agitation, and then, for $5 \mathrm{~min}$ the mixture was sonicated and vortexed for $5 \mathrm{~min}$.

Violet paint: $4.0 \mathrm{~g}$ of $\mathrm{TiO}_{2}$ nanoparticles (Degussa $\mathrm{P} 25$ ), and $40 \mathrm{mg}$ of crystal violet (CV, Sigma-Aldrich, St. Louis, MO, USA) were dispersed in $40 \mathrm{~mL}$ of solution A with constant agitation, and then, for $5 \mathrm{~min}$ the mixture was sonicated and for $5 \mathrm{~min}$, it was vortexed.

\section{Water repellency and self-cleaning in air}

$450 \mu \mathrm{L}$ of paint was inoculated on the glass slides $(2.5 \times 7.5 \mathrm{~cm})$, the slides were tilted until whole surfaces were coated, and dried in the dark room for $3 \mathrm{~h}$. After drying, the samples were washed using deionized (DI) water to ensure removal of non-combined CV or TBO. To test water repellency, $0.5 \mathrm{~mL}$ of deionized (DI) water was fallen on to the treated samples at a height of $\sim 20 \mathrm{~mm}$. To test the self-cleaning property of the samples, iron oxide powder was loaded on to the samples to mimic dirt, and then $1 \mathrm{ml}$ of DI water was fallen on to the 
samples using a pipette. The water repellency and self-cleaning tests were recorded using a smartphone camera (Galaxy S5, Samsung Electronics Co., Ltd, Suwon, South Korea)

\section{Water contact angle measurement of white, blue, and violet painted surfaces in air}

As shown in Figure S1, the equilibrium water contact angle on the paint coated samples was examined by a contact angle meter (First Ten Angstroms, Inc., Portsmouth, Virginia, USA). A DI water droplet (volume $5 \mu \mathrm{L}$ ) was put onto the surface of samples, images were captured on and analyzed by Surftens 4.5 software. The contact angle hysteresis was measured using "add and remove volume" method. The contact angle hysteresis was investigated by the variation of advanced angle and receding angle ${ }^{40}$.

\section{Water contact angle measurement of the painted surface in hexadecane}

The painted samples were immersed in hexadecane and droplets of DI water containing Congo red dye (Sigma-Aldrich, St. Louis, MO, USA) were put onto the treated and untreated sample. It was photographed from the side and then analyzed by Surftens 4.5 software.

\section{Water repellency and self-cleaning in air after hexadecane contamination}

To make oil-contaminated surfaces, the painted glass slides were dipped in hexadecane, and then, from a height of $\sim 20 \mathrm{~mm}, 0.5 \mathrm{~mL}$ of DI water containing Congo red dye was dropped on to the surface of the samples which were tilted at an angle of $20^{\circ}$.

for the self-cleaning test of the oil-contaminated sample, vanadium oxide powder was placed on to the contaminated samples and then $0.5 \mathrm{ml}$ DI water was fallen on to samples which were tilted at an angle of $20^{\circ}$ using pipette.

\section{Measurement of UV-vis spectrum}

As shown in Figure S2, the UV-vis absorption spectra for the paint coated samples were examined by UV-Vis Spectrometer (PerkinElmer Inc., Winter St., CT, USA). Absorption was examined in the wavelengths of 400-900 nm. 


\section{SEM and AFM Analysis}

Scanning Electron Microscopy (SEM, JEOL Inc., Peabody, MA, USA) was used to observe the surface morphology of the paint coated samples at an accelerating voltage of 5 $\mathrm{kV}$. Images were captured using SEMAfore software. Fine gold particles were deposit onto $\mathrm{s}$ ample to eliminate surface charging. Atomic force microscopy (AFM, EeasyScan 2 AFM, Nanosurf, Liestal, Switzerland) was employed to determine a roughness of the sample surface and it was investigated using tapping mode.

\section{Bactericidal testing}

For bactericidal testing, the surface of glass slides was coated by $450 \mu \mathrm{L}$ paint and then dried in the dark room for $3 \mathrm{~h}$. The bactericidal activity of the samples was investigated in Escherichia coli ATCC 25922 and Staphylococcus aureus NCTC 13143. E. coli and S. aureus were stored at $-70^{\circ} \mathrm{C}$ in brain-heart-infusion broth (BHI broth, Oxoid Ltd., Hampshire, England, UK) with 20\% glycerol and incubated on MacConkey agar (Oxoid Ltd., Hampshire, England, UK) and Mannitol salt agar (Oxoid Ltd.), respectively. One bacterial colony was inoculated into $10 \mathrm{ml} \mathrm{BHI} \mathrm{broth} \mathrm{and} \mathrm{cultured} \mathrm{in} \mathrm{shaking} \mathrm{incubator}(200 \mathrm{rpm})$ at $37^{\circ} \mathrm{C}$. After incubation for $18 \mathrm{~h}$, the bacteria were harvested by centrifugation $\left(21^{\circ} \mathrm{C}, 5000 \mathrm{rpm}\right.$ for 10 min), washed using $10 \mathrm{~mL}$ of phosphate buffered saline (PBS), and centrifuged again to recover the bacteria which were re-suspended in $10 \mathrm{~mL}$ of PBS. The washed suspension was diluted 1000-fold in order to obtain $\sim 10^{6}$ colony forming units per millilitre (CFU/mL). As shown in Figure $\mathrm{S} 3,75 \mu \mathrm{L}$ of bacterial suspension was inoculated onto sterilized glass slide $(2.5 \times 7.5 \mathrm{~cm})$, the glass slide was overturned and plated on the paint coated sample. The samples were loaded in petri dishes with wet paper to keep humidity, and they were exposed to white light. another set of samples was placed in the dark room. White light intensity ranged from 3900 to $5300 \mathrm{~lx}$, and the emission wavelength ranged from 400 to $730 \mathrm{~nm}$ 
(Figure S4). The samples were located into $40 \mathrm{~mL}$ PBS after white light exposure, and mixed using a vortex mixer for 1 min to ensure that the bacteria were recovered from the surface of the sample. The bacterial suspension was concentrated into $450 \mu \mathrm{L}$ by centrifugation $(5000$ $\mathrm{rpm}$ at $21^{\circ} \mathrm{C}$ for $20 \mathrm{~min}$ ), plated onto agar; (MacConkey agar for E. coli, and mannitol salt agar for S. aureus). After $24 \mathrm{~h}$ incubation at $37^{\circ} \mathrm{C}$, the bacteria colonies on the plates were counted.

\section{Test of bacterial adhesion}

The adhesion of E. coli and S. aureus was tested on the glass control and the paint coated samples. Glass slides were dipped into paint solution and then dried in the dark room for $3 \mathrm{~h}$. After being washed using DI water, the samples were placed vertically in $30 \mathrm{~mL}$ of bacterial suspension containing $\sim 10^{10} \mathrm{CFU}$ for $3 \mathrm{~min}$, and then were placed into $30 \mathrm{ml}$ of PBS and vortexed for $1 \mathrm{~min}$ to be sure that all bacteria were recovered from the surface of the sample. The bacterial suspension was concentrated into $450 \mu \mathrm{L}$ by centrifugation $\left(5000 \mathrm{rpm}\right.$ at $21^{\circ} \mathrm{C}$ for $20 \mathrm{~min}$ ), serially diluted and plated on to agar. After $24 \mathrm{~h}$ incubation at $37^{\circ} \mathrm{C}$, the bacteria colonies on the plates were counted.

\section{Preparation of paint and double side tape treated glass slides and robust test}

As shown Figure S5, double side tapes were attached onto glass slides. and then the tape attached samples were coated by white, blue, violet paints. The coated samples were placed in dark room for $6 \mathrm{~h}$. After drying, the painted sample was place onto sandpaper (CAMI grit no. 150) and weight of $40 \mathrm{~g}$ was placed on the glass. The painted glass moved back and forth for $8 \mathrm{~cm}$ along ruler. This process defined as one cycle. The water contact angle of the treated sample was examined at each cycle.

Water repellency and stability tests of white, blue, and violet particles 
The white, violet, and violet particles were produced by ethanol evaporation and top-down process (grinding process). To determine water repellency of the particles, the particles were attached to the surface of glass slide using double sided tape and then droplets of DI water containing Congo red dye were dropped on to the particles. The particles were dropped into DI water to determine leaching of $\mathrm{CV}$ or TBO dye and $10 \mu \mathrm{L}$ of DI water containing Congo red dye was placed on the surface of the particles which were floated on DI water.

\section{Statistical analyses}

T-test statistical analysis on results was conducted by SPSS software (version 12.0, SPSS, Inc ., Chicago, IL, USA)

\section{Results and Discussion}

As shown in Figure 1(a), white, blue, and violet paints were produced. Glass slides were painted and then dried in the dark room for $3 \mathrm{~h}$. After drying, samples were washed using deionized (DI) water to remove non-combined CV or TBO. The white paint maintained its color after drying, however, the color became more or less intense in the case of the blue or violet paints. Scanning electron microscopy (SEM) Atomic force microscopy(AFM) were used to examine the surface of the samples and these showed that the $\sim 21 \mathrm{~nm} \mathrm{TiO}_{2}$ nanoparticles in the paint were agglomerated ${ }^{41}$ and the painted surface has a roughness of $\sim 1000 \mathrm{~nm}$ (Table 1).

The UV-vis absorbance spectra of the unpainted control and painted glass slides were measured over the wavelengths of 400-900 nm (Figure 2). The white paint did not show a major absorbance peak between 400-900 nm, while the blue and violet paints showed major absorbance peaks at 589 and $590 \mathrm{~nm}$, respectively, corresponding to the CV and TBO. The adsorption features of $\mathrm{CV}$ and TBO in the wavelength of 400-750 $\mathrm{nm}$ may explain their role on photosensitizer using white light. 
The water contact angle of the control and painted glass was measured. As shown in Figure 3 (a), the control gave water contact angles of $5.9^{\circ}$, indicating superhydrophilic character. However, the painted glass surfaces gave the water contact angles higher than $160^{\circ}$, indicating that they are superhydrophobic (Table 1$)^{37}$. To determine the water repellence of the paints, $0.5 \mathrm{~mL}$ of water was dropped on to the samples. As shown in Movie S1-4 and Figure S6, water droplets were trapped on the surface of the control glass slide whereas the water droplets simply rolled off without wetting the surface on all the painted surfaces. The water rolling phenomenon resulted from superhydrophobicity of the paints giving a high water contact angle $\left(>160^{\circ}\right)$ and low roll off angle $\left(<5^{\circ}\right)$. The self-cleaning experiment represented that after water falling, the dirt contained within the water remained on the surface of the control material while the droplets rolled off on the treated surface, they carried away the dirt. (Movie S5-8 and Figure S7). This phenomenon can be explained in that the rough surface with low surface energy significantly reduces the contact between water droplet and the surface. This considerably reduces the adhesion force of water and surface. Thus, the dirt was washed away by the droplets because adhesion of dirt to the surface is much weaker than that of water droplet to the dirt ${ }^{42}$.

Previous studies showed that superhydrophobic surfaces lose their water repellency after being partially contaminated by oil ${ }^{18,43}$. This is because oil, a lower surface tension than water, penetrated into the surface. As shown Figure 3 (b), a test of the water repellency of the samples immersed in hexadecane oil showed that water droplets still formed spheres on the painted surface, indicating a water contact angle of $>160^{\circ}$. When samples were immersed into the oil, hexadecane permeated within the surface. Thus, water droplets were supported by both the oil and the surface structure, and formed a sphere. After the oil contamination, water droplets simply slid off on the painted surfaces and their self-cleaning property was 
retained (Movie S9-16 and Figure S8-9). When the painted surfaces were exposed to hexadecane, the oil penetrated within the surfaces ${ }^{44}$. This produces lubricating film on the painted surface, resulting in slippery surfaces ${ }^{45}$.

To determine bacterial adhesion to the control and painted glass surfaces, suspensions of Staphylococcus aureus NCTC 13143 (containing $\sim 1.2 \times 10^{10} \mathrm{CFU}$ ) and Escherichia coli ATCC 25922 (containing $\sim 1.1 \times 10^{10} \mathrm{CFU}$ ) were used. Figure 4 shows the number of $S$. aureus and E. coli attached to the surface of the control and painted surfaces. $4.5 \times 10^{7} \mathrm{CFU}$ of $S$. aureus were adhered to the surface of the control material and statistically significant decreases $(>99.9 \%, \mathrm{P}<0.01)$ in the numbers of $S$. aureus were apparent on the white $(3.2 \times$ $\left.10^{4} \mathrm{CFU}\right)$, blue $\left(1.9 \times 10^{4} \mathrm{CFU}\right)$, and violet painted surfaces $\left(1.6 \times 10^{4} \mathrm{CFU}\right)$. A significant decrease in bacteria attachment was also confirmed with $E$. coli for all three painted surfaces compared to the control (unpainted) surface and significant differences were observed in the numbers of adherent bacteria between the different painted surfaces (the number of bacteria attached onto all of painted surface: $\mathrm{P}<0.01)$. The number of $E$. coli adhered to the surface of the control glass was $2.0 \times 10^{7} \mathrm{CFU}$, whereas the numbers on the white, blue, and violet painted surfaces were $4.9 \times 10^{3}, 2.4 \times 10^{5}$, and $5.7 \times 10^{4} \mathrm{CFU}$, respectively. The reduction in bacterial adhesion is attributed to the superhydrophobicity of the paints. When a superhydrophobic surface is immersed, most of its surface is occupied by fine air bubbles. The air bubbles significantly reduce contact between bacteria and the surface, and the bacteria are unable to cross the air-water interfaces as a result of surface tension ${ }^{42}$ (Figure S10). These results indicate that even though superhydrophobic surfaces are not able to prevent bacterial adhesion completely, they could significantly retard biofilm formation by inhibiting the adhesion.

Figure 5 shows (a) the bactericidal activity of the samples against $S$. aureus in the dark and 
in white light. After $3 \mathrm{~h}$ in the dark, the number of viable bacteria decreased significantly on the white, blue, and violet painted surfaces compared to the control material ( $\mathrm{P}$-value $<0.05)$, and among them, violet paint showed the best bactericidal activity achieving a $1.1 \log$ reduction in bacterial numbers compared to a 0.3 and $0.9 \log$ reduction observed for the white and blue painted surfaces, respectively. In white light, the painted surfaces showed increased bactericidal activity compared to the same material in the dark. After $3 \mathrm{~h}$ white light exposure, a $2.3 \log$ and $3.2 \log$ reduction in the numbers of viable bacteria were confirmed on white and blue paint, respectively, compared to the control material and on the violet painted surface, the numbers of viable bacteria fell to below the detection limit ( $<10 \mathrm{CFU})$. All of the painted materials showed increased bactericidal activity in the light compared to the dark, achieving a 0.7, 2.4 and $3.4 \log$ differences in bacterial numbers for the white, blue, and violet paints, respectively.

Figure 5 (b) shows the bactericidal activity of the paints against E. coli in dark and in the white light. In contrast to $S$. aureus, after $4 \mathrm{~h}$ in the dark, no reduction in the number of viable bacteria was confrmed on any of the painted surfaces, and even after $4 \mathrm{~h}$ of white light exposure, the number of viable bacteria did not decrease on either the control or white painted surfaces. But, a statistically significant reduction in the number of viable E. coli was confirmed on the blue and violet painted glass (P-value $<0.01$ at both blue and violet painted glasses). Compared to the control material, a $2.6 \log$ reduction in the numbers of viable bacteria were confirmed on the blue painted surface, and on the violet painted surface, the numbers of viable bacteria had fallen to below the detection limit ( $>5 \log$ reduction).

$\mathrm{TiO}_{2}$ nanoparticles, $\mathrm{CV}$, and $\mathrm{TBO}$ used in this study are known to have some bactericidal activity in the absence of light $27,46-47$. Testing of the bactericidal activity of our materials against $S$. aureus in the dark showed that $\mathrm{TiO}_{2}$ nanoparticles, $\mathrm{CV}$, and $\mathrm{TBO}$ keep their 
intrinsic bactericidal property after being incorporated into paint. However, the paints did not have bactericidal activity against $E$. coli in the dark, and despite the longer exposure to white light compared to $S$. aureus, E. coli was less susceptible overall. It is likely that the difference in susceptibility between S. aureus, a Gram-positive bacterium, and E. coli, a Gram-negative bacterium, is due to their different cell wall structure. The cell wall of Gram-positive bacteria consists of a thick peptidoglycan layer, and only one membrane (plasma membrane) whereas Gram-negative bacteria have a more complex cell wall with a relatively thin layer of peptidoglycan, but an outer membrane in addition to the plasma membrane. The outer membrane of Gram-negative bacteria is known to reduce the permeability of many molecules 48 and is often responsible for resisting chemical agents ${ }^{49}$.

After white light exposure, all of the paints showed enhanced bactericidal activity compared to the same material in the dark. However, compared with the blue and violet paints, the activity of white paint was relatively weak. White paint mainly consists of $\mathrm{TiO}_{2}$ nanoparticles which are a UV light-activated antimicrobial agent (LAAA), and the photobactericidal activity of $\mathrm{TiO}_{2}$ is ascribed to $\mathrm{OH}^{-} \cdot$ radicals and other reactive oxygen species (ROS) induced by the light source ${ }^{21,50-51} . \mathrm{As}^{\mathrm{TiO}_{2}}$ is activated by ultraviolet (UV) light ${ }^{52}$ which accounts for a tiny portion of the total radiation in white light, this may explain why the white paint demonstrated less photobactericidal activity than the blue and violet paints. The potent photobactericial activity of blue and violet paints is due to TBO and CV which are well known white light-activated antimicrobial agents (WLAAA). Under white light conditions, the $\mathrm{CV}$ or TBO molecules are excited to a triplet state via an intersystem crossing from a slightly higher energy, shorter lived excited singlet state. The triple state molecules can undergo quenching by molecular oxygen including singlet oxygen $\left({ }^{1} \mathrm{O}_{2}\right)$ formation or interaction with biomolecules in the vicinity generating radical species ${ }^{30}$. The 
${ }^{1} \mathrm{O}_{2}$ and radical species are thought to kill bacteria by oxidative damage to cellular membranes, intracellular proteins and DNA ${ }^{29,53}$. Despite using an identical amount of WLAAA (CV: $40 \mathrm{mg}$, TBO: $40 \mathrm{mg}$ ) in the paints, the bactericidal activity of the blue and violet paints differed; the reduction of viable bacteria on violet paint was $>1.24$ log higher than that of blue paint. This indicates that the violet paint produces more free radical species or singlet oxygen species more than the blue paint, resulting in better kill.

Nano- or micro scale surface structures and superhydrophobic coatings are easily destroyed because of their mechanical weakness resulting in loss of hydrophobicity and this limits their widespread application. In this study, robust superhydrophobic and antimicrobial surfaces were produced using double side tape (Sellotape, Cheshire, UK) and the paints and they were tested at an extremely environmental condition. The painted sample was placed onto sandpaper (CAMI grit no. 150) and $40 \mathrm{~g}$ weight was loaded on to the sample. The applied force on samples was approximately $21.3 \mathrm{~kg} / \mathrm{m}^{2}$. The sample was then moved back and forth for $8 \mathrm{~cm}$ along a plastic ruler. One back and forth movement was defined as one abrasion cycle. Figure 6 (a) shows that the sand paper abrasion test against white, blue, and violet painted glass slides. Previous studies showed that the water contact angle of the robust surface decreased by $13-15^{\circ}$ after repeating abrasion test. ${ }^{54-55}$ However, 10 cycles test in this study showed that after repeating abrasion, the painted surfaces retained a water contact angles of $>158^{\circ}$, low rolling off angle $\left(<0.5^{\circ}\right)$ and contact angle hysteresis $\left(<3.4^{\circ}\right)$, indicating that they are still superhydrophobic. Their colors and the coating thickness of $55 \mu \mathrm{m}$ were also retained (Figure S11). The white, violet, and violet particles were made through ethanol evaporation and top-down process. As shown in Figure 6 (b), the particles retained their respective colors and measurement of the water contact angle showed that the particles remained superhydrophobic. $\mathrm{CV}$ and $\mathrm{TBO}$ dyes used in this study were soluble in water. 
However, dye leaching from the particles was not observed. In ethanol, porous $\mathrm{TiO}_{2}$ nanoparticles absorb dye molecules ${ }^{56}$, and the PFOTES molecules covalently bond to the surface of $\mathrm{TiO}_{2}$ nanoparticles ${ }^{57-58}$. Thus, a PFOTES molecules are bonded on the surface of the dye absorbed $\mathrm{TiO}_{2}$, the nanoparticles have superhydrophobic and the light activated properties (Figure S12).

Previous studies have shown that combination of superhydrophobic agents and bactericidal nanoparticles resulted in no or weak antimicrobial activity although they retained high hydrophobicity. This might be because the superhydrophobic polymer coating reduce the contact surface area between antimicrobial substances and bacteria ${ }^{11,33-39}$. We addressed the problem by the combination of $\mathrm{TiO}_{2}$, WLAAA and PFOTES. As a result, bacteria are killed by ROS diffused from surface containing WLAAA under white light condition.

\section{Conclusion}

This study reports new paints possessing both self-cleaning and white light-activated bactericidal properties. Compared to previous techniques for bactericidal surfaces and superhydrphobic surfaces, the technique developed in this study has several advantages: (i). the paints are easily made; (ii) surface treatment with the paints is simple and fast as commercial paint; (iii) the surfaces have dual functions after one simple process and (iv) the paints can be applied to a wide range of substrates including glass (Figure 1(b)), paper, and plastic (Figure S13). It is expected that these paints may be useful for healthcare and industrial facilities, as well as being applicable in the home for decoration.

\section{Supporting information}

1. Water repellent test of samples. 2. Self-cleaning testing of samples. 3. Water repellent test of samples after hexadecane contamination. 4. Self-cleaning testing of samples after hexadecane contamination. 5. Intensity distribution of the white light which. 6. 
Comparison of the paint coating thickness before and after abrasion test. 7. Chemical structures on the combinations of $\mathrm{TiO}_{2}$ nanoparticle/PFOTES, and $\mathrm{TiO}_{2}$ nanoparticle/PFOTES /TBO, and $\mathrm{TiO}_{2}$ nanoparticle/ PFOTES/CV. 8. White, blue, violet painted plastics (plastic toys) and papers. 


\section{Reference}

(1) Kraigsley, A. M.; Finkel, S. E., Adaptive Evolution in Single Species Bacterial Biofilms. FEMS Microbiol. Lett. 2009, 293, 135-40.

(2) Islander, R. L.; Devinny, J. S.; Mansfeld, F.; Postyn, A.; Shih, H., Microbial Ecology of Crown Corrosion in Sewers. J. Environ. Eng. 1991, 117, 751-770.

(3) Mahapatra, A.; Padhi, N.; Mahapatra, D.; Bhatt, M.; Sahoo, D.; Jena, S.; Dash, D.; Chayani, N., Study of Biofilm in Bacteria from Water Pipelines. J. Clin. Diagn. Res. 2015, 9, DC09-11.

(4) Boyce, J. M., Environmental Contamination Makes an Important Contribution to Hospital Infection. J. Hosp. Infect. 2007, 65, 50-54.

(5) Bagihalli, G. B.; Avaji, P. G.; Patil, S. A.; Badami, P. S., Synthesis, Spectral Characterization, in Vitro Antibacterial, Antifungal and Cytotoxic Activities of $\mathrm{Co}(\mathrm{II}), \mathrm{Ni}(\mathrm{II})$ and $\mathrm{Cu}(\mathrm{II})$ Complexes with 1,2,4-Triazole Schiff Bases. Eur. J. Med. Chem. 2008, 43, 2639-49.

(6) Page, K.; Wilson, M.; Parkin, I. P., Antimicrobial Surfaces and Their Potential in Reducing the Role of the Inanimate Environment in the Incidence of Hospital-Acquired Infections. J. Mater. Chem. 2009, 19, 3819.

(7) Ayliffe, G. A. J.; Collins, B. J.; Lowbury, E. J. L.; Babb, J. R.; Lilly, H. A., Ward Floors and Other Surfaces as Reservoirs of Hospital Infection. J. Hyg. 2009, 65, 515.

(8) Castelli, P.; Caronno, R.; Ferrarese, S.; Mantovani, V.; Piffaretti, G.; Tozzi, M.; Lomazzi, C.; Rivolta, N.; Sala, A., New Trends in Prosthesis Infection in Cardiovascular Surgery. Surg. Infect. 2006, 7 Suppl 2, S45-7.

(9) Monina, K. R. Centers for Disease Control and Prevention Public Health Reports. Healthcare-Associated Infections and Deaths in U.S. Hospitals; 2007.

(10) Bryers, J. D.; Ratner, B. D., Biomaterials Approaches to Combating Oral Biofilms and Dental Disease. BMC oral health 2006, 6 Suppl 1, S15.

(11) Zhang, X.; Wang, L.; Levänen, E., Superhydrophobic Surfaces for the Reduction of Bacterial Adhesion. RSC Adv. 2013, 3, 12003.

(12) Sarkar, D. K.; Saleema, N., One-Step Fabrication Process of Superhydrophobic Green Coatings. Surf. Coat. Technol. 2010, 204, 2483-2486.

(13) Zhang, H.; Lamb, R.; Lewis, J., Engineering Nanoscale Roughness on Hydrophobic Surface-Preliminary Assessment of Fouling Behaviour. STAM 2005, 6, 236-239.

(14) Wang, H.; Fang, J.; Cheng, T.; Ding, J.; Qu, L.; Dai, L.; Wang, X.; Lin, T., One-Step Coating of FluoroContaining Silica Nanoparticles for Universal Generation of Surface Superhydrophobicity. Chem. Commun. 2008, 7, 877-9.

(15) Yang, H.; Jiang, P., Self-Cleaning Diffractive Macroporous Films by Doctor Blade Coating. Langmuir 2010, 26, 12598-604.

(16) Furstner, R.; Barthlott, W.; Neinhuis, C.; Walzel, P., Wetting and Self-Cleaning Properties of Artificial Superhydrophobic Surfaces. Langmuir 2005, 21, 956-61.

(17) Zimmermann, J.; Reifler, F. A.; Fortunato, G.; Gerhardt, L.-C.; Seeger, S., A Simple, One-Step Approach to Durable and Robust Superhydrophobic Textiles. Adv. Funct. Mater. 2008, 18, 3662-3669.

(18) Zhu, Q.; Chu, Y.; Wang, Z.; Chen, N.; Lin, L.; Liu, F.; Pan, Q., Robust Superhydrophobic Polyurethane Sponge as a Highly Reusable Oil-Absorption Material. J. Mater. Chem. A 2013, 1, 5386.

(19) Hasan, J.; Crawford, R. J.; Ivanova, E. P., Antibacterial Surfaces: the Quest for a New Generation of Biomaterials. Trends Biotechnol. 2013, 31, 295-304.

(20) Chen, X.; Schluesener, H. J., Nanosilver: a Nanoproduct in Medical Application. Toxicol. Lett 2008, 176, $1-12$.

(21) Daoud, W. A.; Xin, J. H.; Zhang, Y.-H., Surface Functionalization of Cellulose Fibers with Titanium Dioxide Nanoparticles and Their Combined Bactericidal Activities. Surf. Sci. 2005, 599, 69-75.

(22) Noimark, S.; Allan, E.; Parkin, I. P., Light-Activated Antimicrobial Surfaces with Enhanced Efficacy Induced by a Dark-Activated mechanism. Chem. Sci. 2014, 5, 2216.

(23) Roe, D.; Karandikar, B.; Bonn-Savage, N.; Gibbins, B.; Roullet, J. B., Antimicrobial Surface Functionalization of Plastic Catheters by Silver Nanoparticles. J. Antimicrob. Chemother. 2008, 61, 869-76.

(24) Grass, G.; Rensing, C.; Solioz, M., Metallic Copper as an Antimicrobial Surface. Appl. Environ. Microbiol. 2011, 77, 1541-7.

(25) Salgado, C. D.; Sepkowitz, K. A.; John, J. F.; Cantey, J. R.; Attaway, H. H.; Freeman, K. D.; Sharpe, P. A.; Michels, H. T.; Schmidt, M. G., Copper Surfaces Reduce the Rate of Healthcare-Acquired Infections in the Intensive Care Unit. Infect. Control Hosp. Epidemiol. 2013, 34, 479-86.

(26) Ramsden, J. J., Photocatalytic Antimicrobial Coatings. Nanotechnol. Percept. 2015, 11, 146-168. 
(27) Naik, A.J.T.; Ismail, S.; Kay, C.; Wilson, M.; Parkin, I. P., Antimicrobial Activity of Polyurethane Embedded with Methylene blue, Toluidene Blue and Gold Nanoparticles against Staphylococcus aureus; Illuminated with White Light. Mater. Chem. Phys. 2011, 129, 446-450.

(28) Sehmi, S. K.; Noimark, S.; Bear, J. C.; Peveler, W. J.; Bovis, M.; Allan, E.; MacRobert, A. J.; Parkin, I. P., Lethal Photosensitisation of Staphylococcus aureus and Escherichia coli using Crystal Violet and Zinc OxideEncapsulated Polyurethane, J. Mater. Chem. B, 2015,3, 6490-6500.

(29) Ozkan, E.; Allan, E.; Parkin, I. P., The antibacterial Properties of Light-Activated Polydimethylsiloxane Containing Crystal Violet. RSC Adv. 2014, 4, 51711-51715.

(30) Noimark, S.; Bovis, M.; MacRobert, A. J.; Correia, A.; Allan, E.; Wilson, M.; Parkin, I. P., Photobactericidal Polymers; the Incorporation of Crystal Violet and Nanogold into Medical Grade Silicone. RSC Adv. 2013, 3, 18383.

(31) Piccirillo, C.; Perni, S.; Gil-Thomas, J.; Prokopovich, P.; Wilson, M.; Pratten, J.; Parkin, I. P., Antimicrobial Activity of Methylene Blue and Toluidine Blue O Covalently Bound to a Modified Silicone Polymer Surface. J. Mater. Chem. 2009, 19, 6167.

(32) Noimark, S.; Dunnill, C. W.; Kay, C. W. M.; Perni, S.; Prokopovich, P.; Ismail, S.; Wilson, M.; Parkin, I. P., Incorporation of Methylene Blue and Nanogold into Polyvinyl Chloride Catheters; a New Approach for LightActivated Disinfection of Surfaces. J. Mater. Chem. 2012, 22, 15388.

(33) Ozkan, E.; Crick, C. C.; Taylor, A.; Allan, E.; Parkin, I. P., Copper-Based Water Repellent and Antibacterial Coatings by Aerosol Assisted Chemical Vapour Deposition. Chem. Sci. 2016, 7, 5126-5131.

(34) Berendjchi, A.; Khajavi, R.; Yazdanshenas, M. E., Fabrication of Superhydrophobic and Antibacterial Surface on Cotton Fabric by Doped Silica-Based Sols with Nanoparticles of Copper. Nanoscale Res. Lett. 2011, 6, 594.

(35) Chung, J. S.; Kim, B. G.; Shim, S.; Kim, S. E.; Sohn, E. H.; Yoon, J.; Lee, J. C., SilverPerfluorodecanethiolate Complexes Having Superhydrophobic, Antifouling, Antibacterial Properties. J. Colloid Interface Sci. 2012, 366, 64-9.

(36) Shateri Khalil-Abad, M.; Yazdanshenas, M. E., Superhydrophobic Antibacterial Cotton Textiles. J. Colloid Interface Sci. 2010, 351 (1), 293-8.

(37) Tang, H.; Wang, H.; He, J., Superhydrophobic Titania Membranes of Different Adhesive Forces Fabricated by Electrospinning. J. Phys. Chem C 2009, 113, 14220-14224.

(38) Yamauchi, K.; Yao, Y.; Ochiai, T.; Sakai, M.; Kubota, Y.; Yamauchi, G., Antibacterial Activity of Hydrophobic Composite Materials Containing a Visible-Light-Sensitive Photocatalyst. J. Nanotech. 2011, 2011, $1-7$.

(39) Privett, B. J.; Youn, J.; Hong, S. A.; Lee, J.; Han, J.; Shin, J. H.; Schoenfisch, M. H., Antibacterial Fluorinated Silica Colloid Superhydrophobic Surfaces. Langmuir 2011, 27, 9597-601.

(40) Chang, F.-M.; Hong, S.-J.; Sheng, Y.-J.; Tsao, H.-K., High Contact Angle Hysteresis of Superhydrophobic Surfaces: Hydrophobic Defects. Appl. Phys. Lett. 2009, 95, 064102.

(41) Lu, Y.; Sathasivam, S.; Song, J.; Crick, C. R.; Carmalt, C. J.; Parkin, I. P., Repellent materials. Robust selfCleaning Surfaces that Function When Exposed to either Air or Oil. Science 2015, 347, 1132-5.

(42) Truong, V. K.; Webb, H. K.; Fadeeva, E.; Chichkov, B. N.; Wu, A. H.; Lamb, R.; Wang, J. Y.; Crawford, R. J.; Ivanova, E. P., Air-Directed Attachment of Coccoid Bacteria to the Surface of Superhydrophobic Lotus-Like Titanium. Biofouling 2012, 28, 539-50.

(43) Tuteja, A.; Choi, W.; Mabry, J. M.; McKinley, G. H.; Cohen, R. E., Robust Omniphobic Surfaces. PNAS 2008, 105, 18200-5.

(44) Shang, B.; Wang, Y.; Peng, B.; Deng, Z., Bioinspired Polydopamine Particles-Assisted Construction of Superhydrophobic Surfaces for Oil/Water Separation. J. Colloid Interface Sci. 2016, 482, 240-51.

(45) Wong, T. S.; Kang, S. H.; Tang, S. K.; Smythe, E. J.; Hatton, B. D.; Grinthal, A.; Aizenberg, J., Bioinspired self-repairing slippery surfaces with pressure-stable omniphobicity. Nature 2011, 477, 443-7.

(46) Verdier, T.; Coutand, M.; Bertron, A.; Roques, C., Antibacterial Activity of TiO2 Photocatalyst Alone or in Coatings on E. coli: The Influence of Methodological Aspects. Coatings 2014, 4, 670-686.

(47) Komerik, N.; Wilson, M., Factors Influencing the Susceptibility of Gram-Negative Bacteria to Toluidine Blue O-Mediated Lethal Photosensitization. J. Appl. Microbiol. 2002, 92, 618-623.

(48) Tortora, G.; Funke, R. B.; Case, L. C., Microbiology; An Introduction. Addison-Wesley Longman, Inc.: New York, 2001.

(49) Fu, G.; Vary, P. S.; Lin, C. T., Anatase $\mathrm{TiO}_{2}$ Nanocomposites for Antimicrobial Coatings. J. Phys. Chem B 2005, 109, 8889-98.

(50) Zhao, L.; Chu, P. K.; Zhang, Y.; Wu, Z., Antibacterial Coatings on Titanium Implants. J. Biomed. Mater. Res. B Appl. Biomater. 2009, 91, 470-80.

(51) Visai, L.; De Nardo, L.; Punta, C.; Melone, L.; Cigada, A.; Imbriani, M.; Arciola, C. R., Titanium Oxide 
Antibacterial Surfaces in Biomedical Devices. Int. J. Artif. Organs 2011, 34, 929-46.

(52) Hashimoto, K.; Irie, H.; Fujishima, A., $\mathrm{TiO}_{2}$ Photocatalysis: a Historical Overview and Future Prospects. Jpn. J. Appl. Phys. 2005, 44, 8269-8285.

(53) Maisch, T., Resistance in Antimicrobial Photodynamic Inactivation of Bacteria. Photochem. Photobiol. Sci. 2015, 14, 1518-26.

(54) Wang, G.; Liu, S.; Wei, S.; Liu, Y.; Lian, J.; Jiang, Q., Robust Superhydrophobic Surface on Al Substrate With Durability, Corrosion Resistance and Ice-Phobicity. Sci. Rep. 2016, 6, 20933.

(55) Wang, N.; Lu, Y.; Xiong, D.; Carmalt, C. J.; Parkin, I. P., Designing Durable and Flexible Superhydrophobic Coatings and Its Application in Oil Purification. J. Mater. Chem. A 2016, 4, 4107-4116.

(56) Luo, X.; Kim, J. H.; Ahn, J. Y.; Lee, D.; Kim, J. M.; Lee, D. G.; Kim, S. H., Electrospraying-Assisted Rapid Dye Molecule Uptake on the Surfaces of TiO2 Nanoparticles for Speeding Up Dye-Sensitized Solar Cell Fabrication. Sol. Energ. Mat. and Sol. Cells 2016, 144, 411-417.

(57) Cech, J.; Taboryski, R., Stability of FDTS Monolayer Coating on Aluminum Injection Molding Tools. Appl. Surf. Sci. 2012, 259, 538-541.

(58) Barlow, S. M.; Raval, R., Complex Organic Molecules at Metal Surfaces: Bonding, Organisation and Chirality. Surf. Sci. Rep. 2003, 50, 201-341. 


\section{Table Legend}

Table 1. water contact angle, rolling off angle, contact angle hysteresis, and surface roughness of untreated, white painted, blue painted, and violet painted surfaces.

\section{Figure Legends}

Fig. 1 (a) white, blue, and violet paint solutions, and (b) the painted glass slides and SEM and AFM images of the painted glass samples

Fig. 2. UV-vis absorption spectra of an unpainted glass slide (control), and glass slides pained with white, blue, and violet paints. Absorption spectra were collected at wavelengths 400-900 nm.

Fig. 3. Water contact angle of control, and the painted glasses in (a) air and (b) hexadecane ${ }^{1}$ WCA: Water Contact Angle

Fig. 4. Numbers of (a) S. aureus and (b) E. coli adhering to the surface of control, white, blue, and violet painted glass slides. The painted glass slides were immersed into bacterial solution for $3 \mathrm{~min}$.

Fig. 5. Bactericidal activity of unpainted glass slide (control) and white, blue, and violet painted glass slides against (a) S. aureus and (b) E. coli: samples inoculated with bacteria were exposed to light intensities ranging from 3900 to $5300 \mathrm{~lx}$ for $3 \mathrm{~h}$ and $4 \mathrm{~h}$, respectively. In all tests, the temperature was maintained at a constant $20^{\circ} \mathrm{C}$.

Fig. 6. (a) Sand paper abrasion test of the paint and double side tape treated glass slides and (b) water repellent and stable tests of white, blue, and violet particles. 
1

2

3

4

5

6

7

8

9

10

11

12

13

14

15

16

17

18

19

20

21

Table 1. water contact angle, rolling off angle, contact angle hysteresis, and surface roughness of untreated, white painted, blue painted, and violet painted surfaces.

\begin{tabular}{ccccc}
\hline Sample & $\begin{array}{c}\text { Water contact } \\
\text { angle }\left({ }^{\mathrm{O}}\right)\end{array}$ & $\begin{array}{c}\text { Rolling off } \\
\text { angle }\left({ }^{\circ}\right)\end{array}$ & $\begin{array}{c}\text { Contact angle } \\
\text { hysteresis }\left({ }^{\circ}\right)\end{array}$ & $\begin{array}{c}\text { Surface roughness } \\
(\mathrm{Sa}, \mathrm{nm})\end{array}$ \\
\hline $\begin{array}{c}\text { Untreated surface } \\
\text { (glass slide) }\end{array}$ & $5.9 \pm 0.6$ & $\mathrm{n} / \mathrm{a}$ & $\mathrm{n} / \mathrm{a}$ & $5.1 \pm 0.8$ \\
$\begin{array}{c}\text { White painted } \\
\text { surface }\end{array}$ & $164.4 \pm 2.2$ & $0 \pm 0$ & $0.4 \pm 0.5$ & $1150.7 \pm 610.5$ \\
$\begin{array}{c}\text { Blue painted } \\
\text { surface }\end{array}$ & $163.6 \pm 1.6$ & $0 \pm 0$ & $0.8 \pm 0.6$ & $1046.1 \pm 757.6$ \\
$\begin{array}{c}\text { Violet painted } \\
\text { surface }\end{array}$ & $163.1 \pm 1.8$ & $0 \pm 0$ & $0.9 \pm 1.0$ & $1027.8 \pm 61.9$ \\
\hline
\end{tabular}




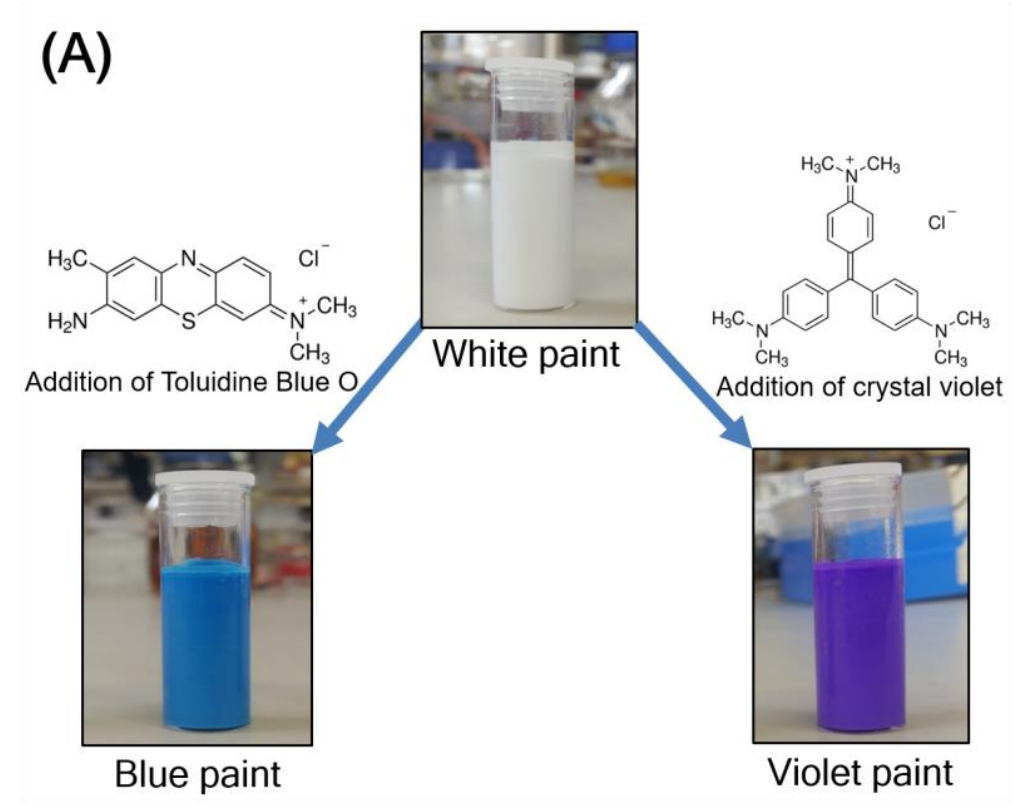

\section{(B)}
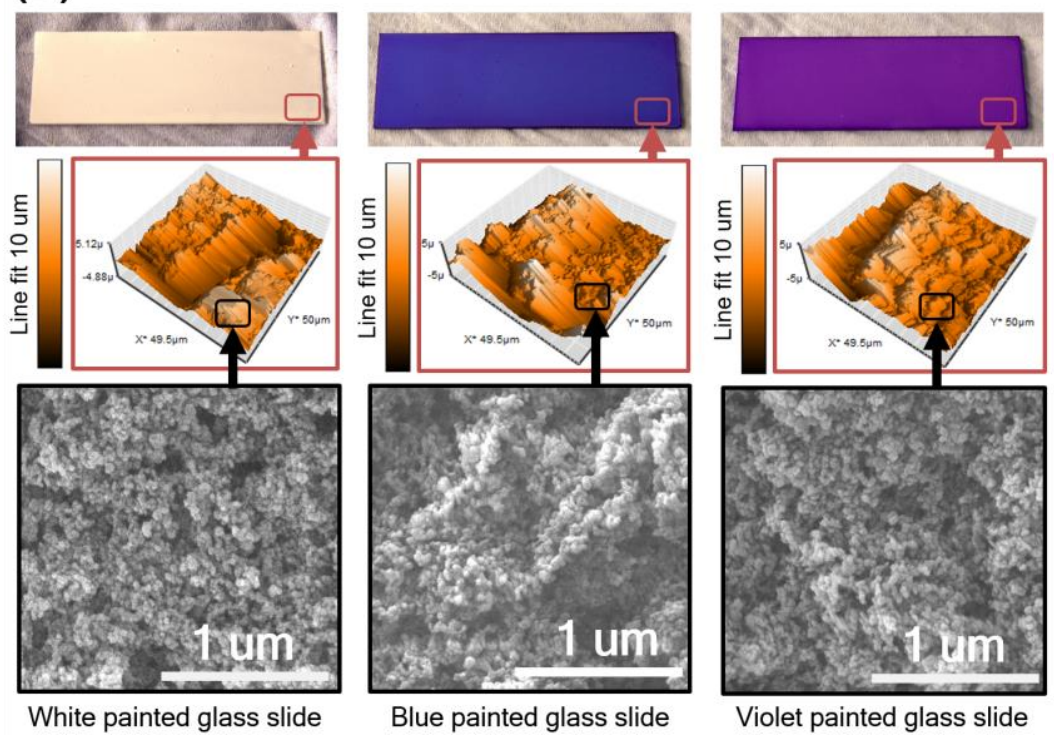

Blue painted glass slide

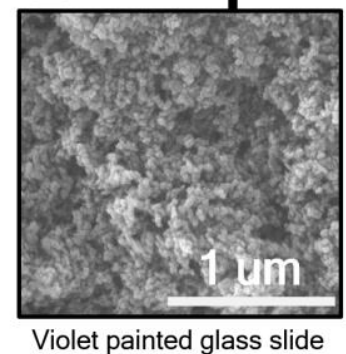

Fig. 1 (a) white, blue, and violet paint solutions, and (b) the painted glass slides and SEM and AFM images of the painted glass samples 


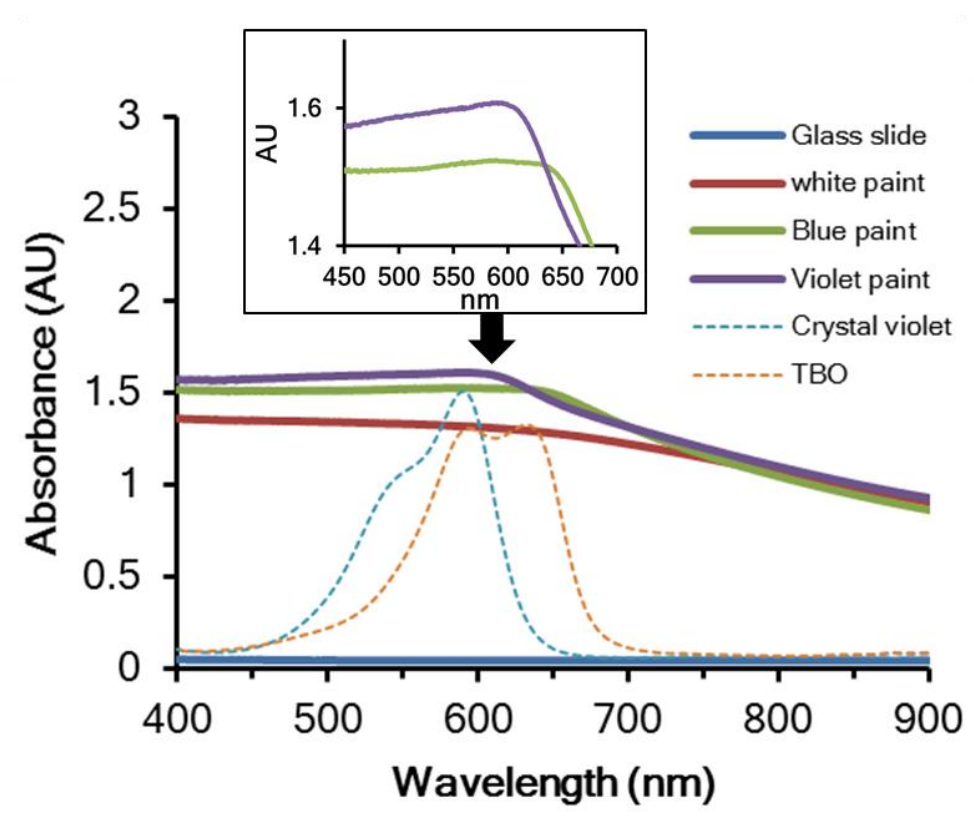

Fig. 2. UV-vis absorption spectra of an unpainted glass slide (control), and glass slides pained with white, blue, and violet paints. Absorption spectra were collected at wavelengths 400 $900 \mathrm{~nm}$. 


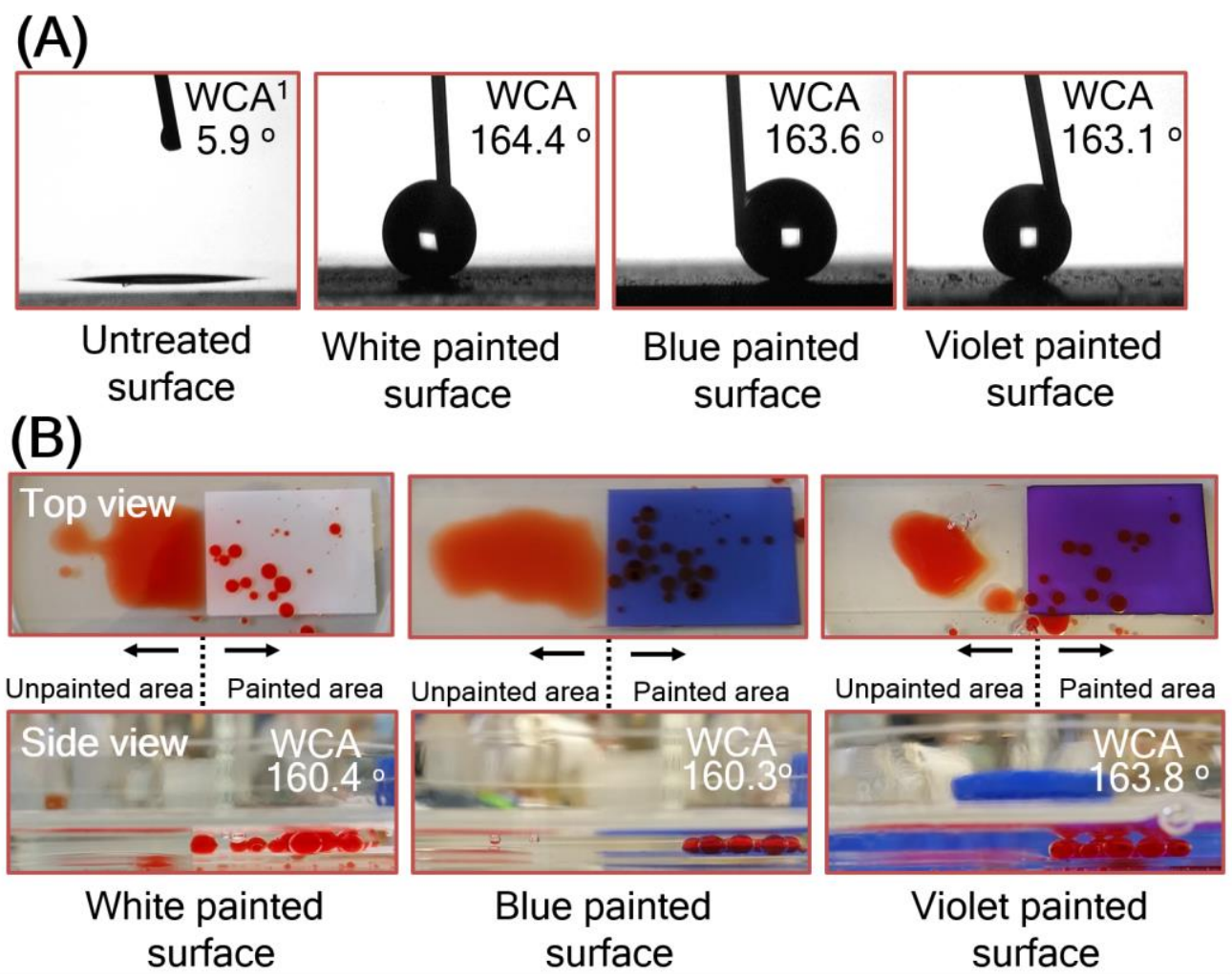

Fig. 3. Water contact angle of control, and the painted glasses in (a) air and (b) hexadecane ${ }^{1}$ WCA: Water Contact Angle 
1

2

3

4

5

6

7

8

9

11

12

13

14

15

16

17

18

19

20

21

22

23

24

25

26

27

28

29

30

31

32

33

34

35

36

37

38

39

40

41

42

43

44

45

46

47

48

49

50

51

52

53

54

55

56

57

58

59

60
(A)

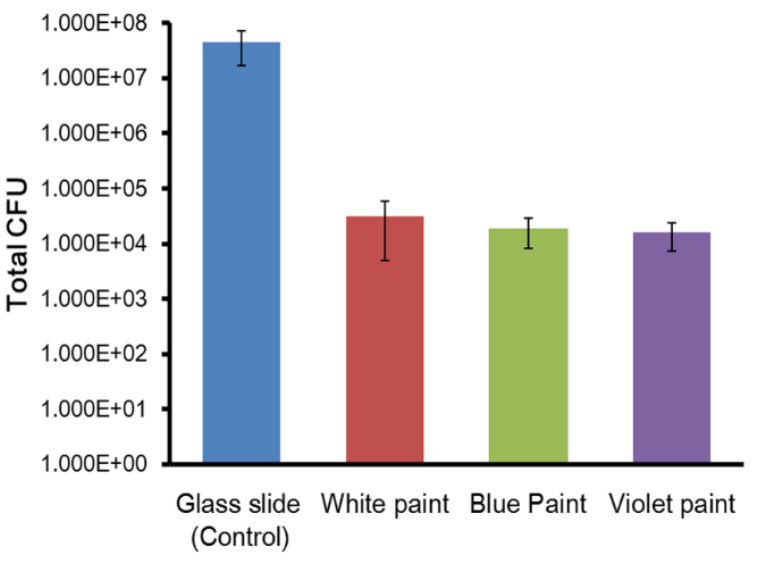

(B)

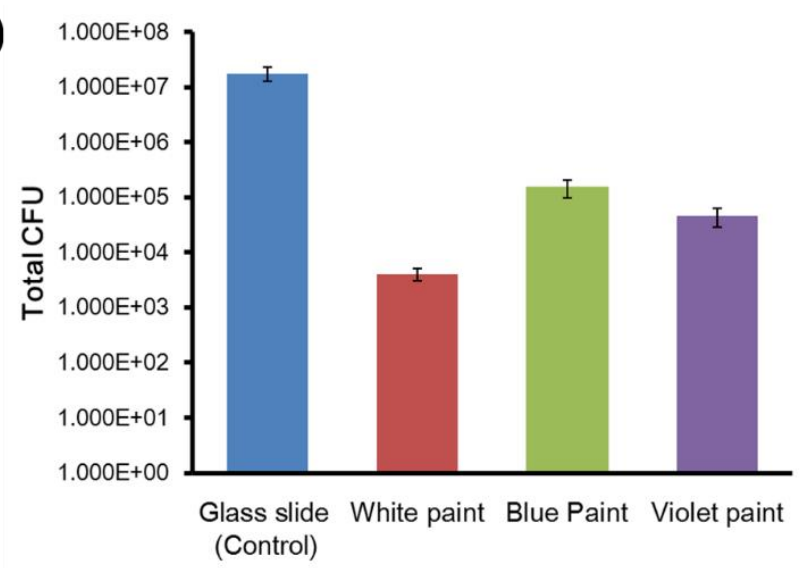

Fig. 4. Numbers of (a) S. aureus and (b) E. coli adhering to the surface of control, white, blue, and violet painted glass slides. The painted glass slides were immersed into bacterial solution for $3 \mathrm{~min}$. 
(A)

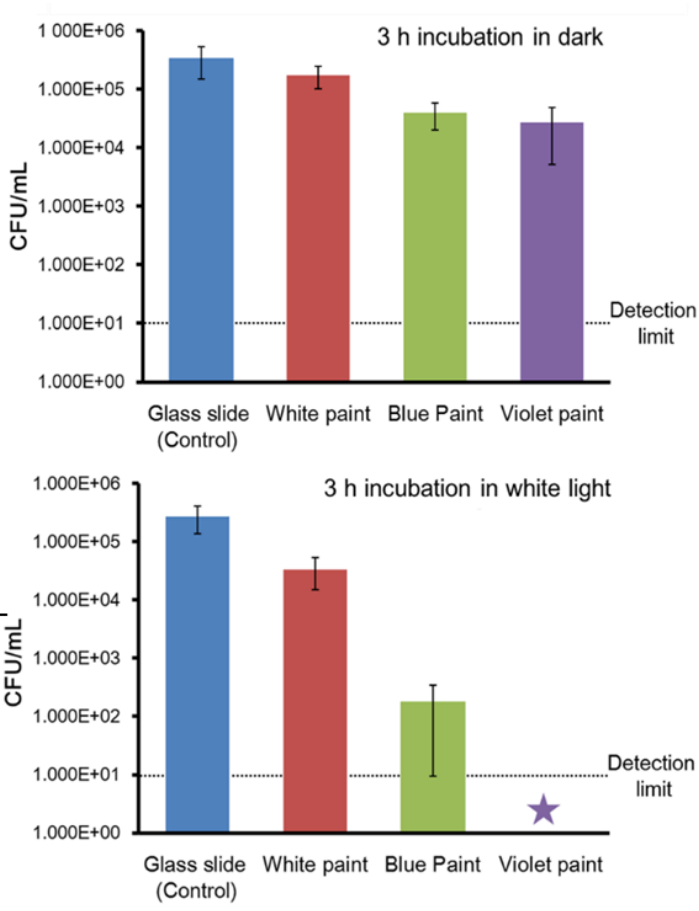

(B)
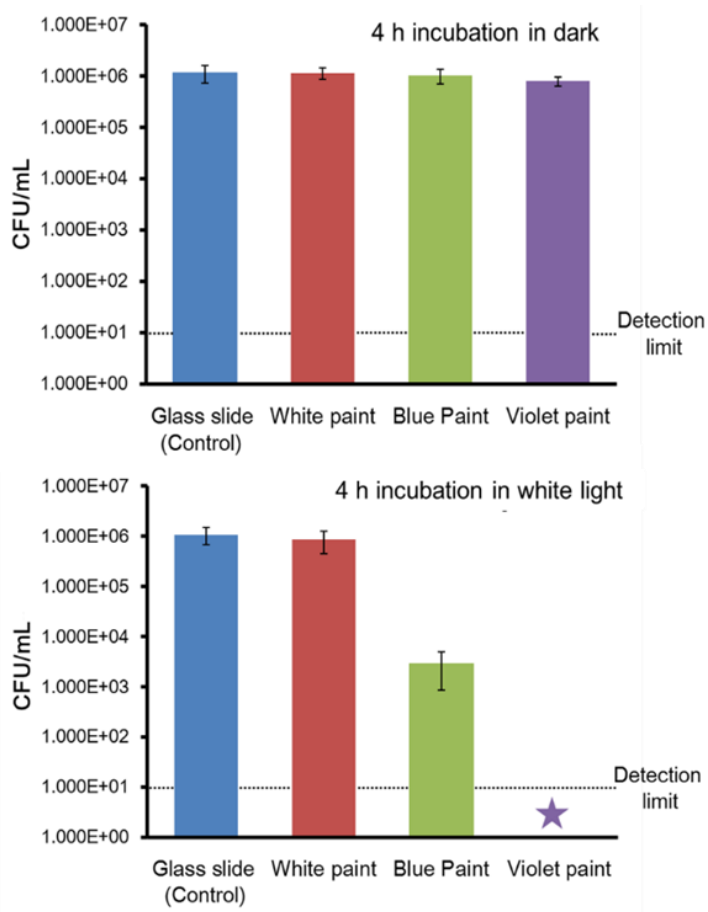

Fig. 5. Bactericidal activity of unpainted glass slide (control) and white, blue, and violet painted glass slides against (a) S. aureus and (b) E. coli: samples inoculated with bacteria were exposed to light intensities ranging from 3900 to $5300 \mathrm{~lx}$ for $3 \mathrm{~h}$ and $4 \mathrm{~h}$, respectively. In all tests, the temperature was maintained at a constant $20^{\circ} \mathrm{C}$.

${ }^{1}$ Colony forming unit/ $\mathrm{mL}$ : Colony forming Unit (CFU) is derived from viable counting whereby a single bacterial colony is assumed to have arisen from a single bacterium $\star$ Detection limit: <10 CFU 


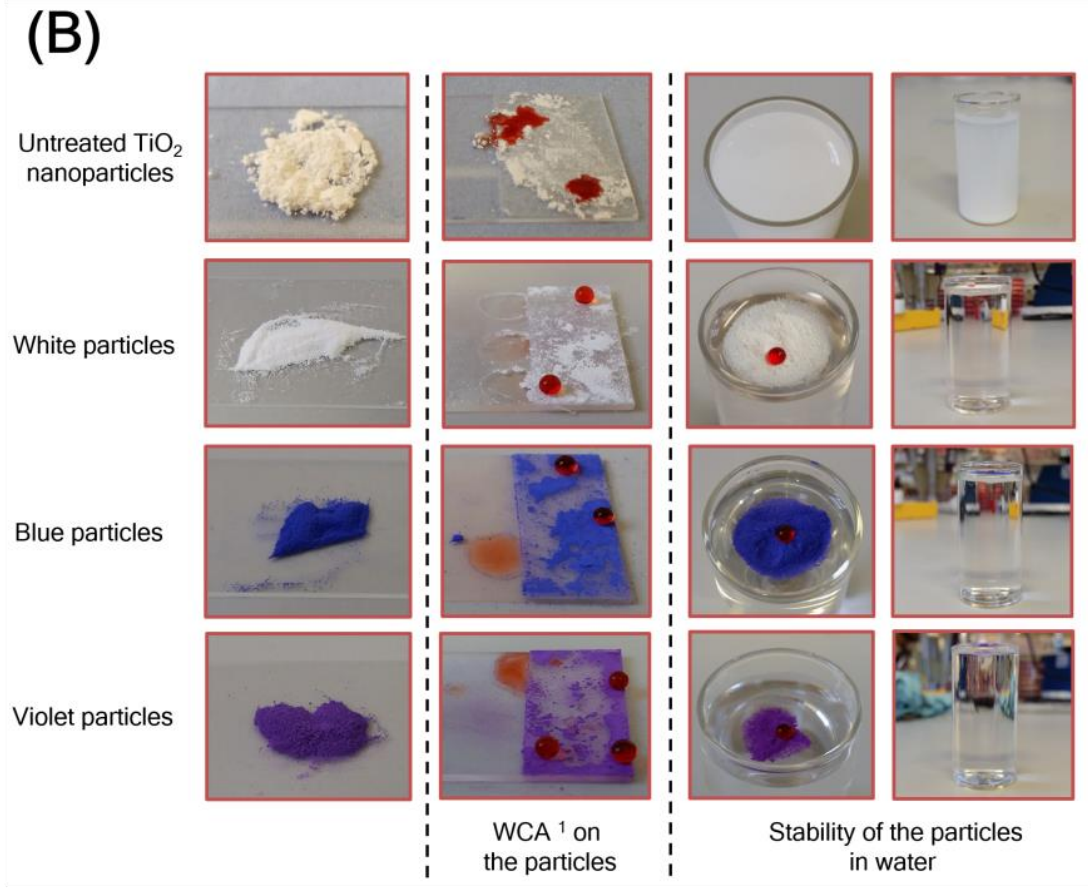

Fig. 6. (a) Sand paper abrasion test of the paint and double side tape treated glass slides and (b) water repellent and stable tests of white, blue, and violet particles.

\section{${ }^{1}$ WCA: Water Contact Angle}


$\underline{\text { Graphical abstract }}$
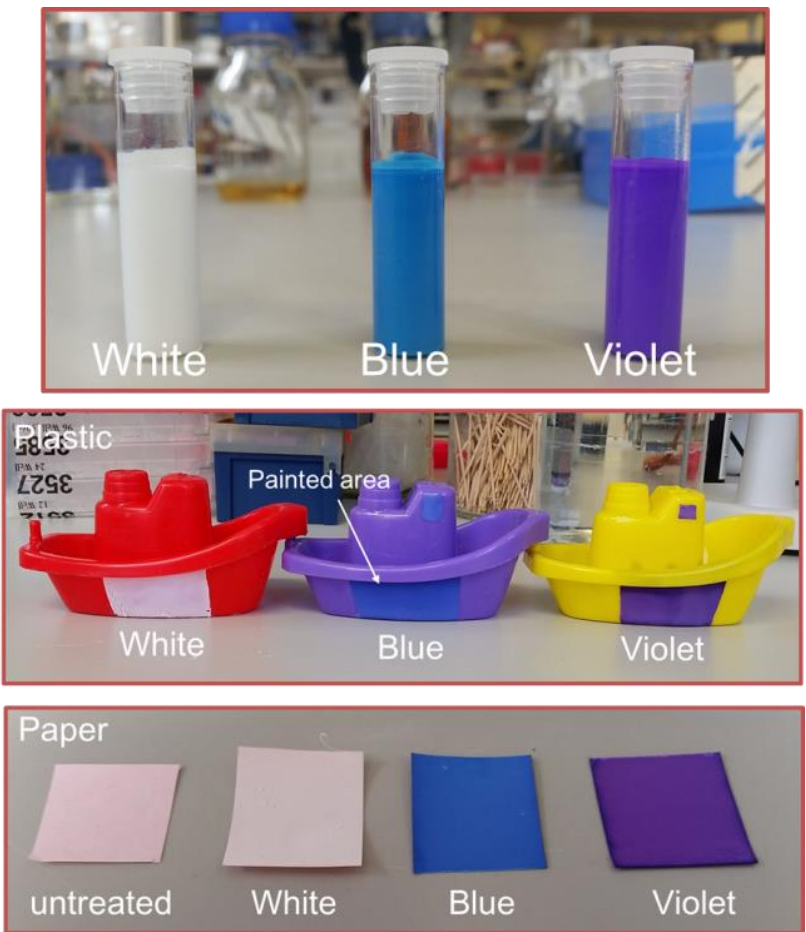